\title{
O LEGADO DOS JESUÍTAS NA EDUCAĈ̣̃O BRASILEIRA
}

\author{
Wilson Alves de Paiva" \\ Pontifícia Universidade Católica de Goiás (PUC-Goiás)
}

RESUMO: Este artigo tem como objetivo refletir sobre o legado dos jesuítas para a formação do pensamento educacional brasileiro, sobretudo em sua pedagogia, cujo caráter disciplinador e dogmático permaneceu o mesmo após a expulsão da Companhia de Jesus, ocorrida no século XVIII. A dificuldade de substituir a presença dos jesuítas desde o início da colonização e a sua expansão a todo o território brasileiro ao longo de sua atuação por mais de dois séculos não tem a ver somente com a falta de fundos, mas com a falta de uma política de real valorização da escola pública. E, no que diz respeito às práticas pedagógicas, falta uma retomada de certos ideais dos próprios jesuítas; dos ideais reformistas de educadores que pensaram um ambiente mais lúdico, prático, dinâmico e voltado para as necessidades de uma formação crítica e reflexiva.

Palavras-chave: Educação brasileira. Teorias da educação. Tendências pedagógicas. Jesuítas.

\section{THE JESUIT HERITAGE IN BRAZILIAN EDUCATION}

ABSTRACT: This paper aims to reflect about jesuit's legacy to the formation of Brazilian educational thought, especially about pedagogy, whose strong discipline and dogmatic characteristics remained even after the Society of Jesus was expelled by the end on the XVIII century. The difficulty in replacing the presence of the Jesuits since the beginning of colonization and its expansion throughout Brazil, as well as its activities for more than two centuries, is related not only with the lack of funds, but the lack of a real policy on defense of public schools. Regarding to teaching practices, we lack a revival of the ideals of reformist educators who thought a more practical and more dynamic education focused on the needs of a critical and reflective formation.

Keywords: Brazilian education. Education theories. Pedagogical tendencies. The Jesuits.

http://dx.doi.org/10.1590/0102-4698136933

"Doutor em Filosofia da Educação pela Universidade de São Paulo. Professor e pesquisador do Programa de Pós-Graduação em Educação e da Escola de Formação de Professores e Humanidades da PUC-GO. E-mail: wap@usp.br 


\section{INTRODUÇÃO}

Diversas são as raízes que fundamentam as tendências pedagógicas desenvolvidas em nosso país ao longo de sua história. E são essas tendências que, igualmente, lançam as bases para o desenvolvimento do pensamento educacional brasileiro em sua riqueza teórica e diversidade prática. Malgrado a multiplicidade de teorias que influenciaram de uma forma ou de outra a trajetória da educação brasileira nos séculos XIX e XX, com extensão até os dias de hoje, durante os três primeiros séculos da colonização o processo educativo seguiu praticamente inalterado. Rigidamente amparado numa concepção religiosa de mundo, o período forjou uma escola de racionalidade dedutiva, que defendia o ensino das verdades consagradas pelo cânone escolástico, complementado, sobretudo, pelo currículo das sete artes liberais (trivium e quadrivium), bem como de algumas atividades práticas. É o caso do trabalho educativo dos religiosos da Companhia de Jesus que por aqui aportaram em 1549 e legaram um caráter próprio à forma de educar e ao modo de pensar a organização do processo educacional como um todo. Sustentada na hierarquia, a organização educativa forjou uma relação amparada na autoridade de quem detinha o conhecimento e na valorização da tradição como instrumento de manutenção da ordem, como era concebida pela Igreja. E não poderia ser diferente, uma vez que, como afirma Paiva (2012, p. 137), "no século XVI, o pensar era fundamentalmente religioso".

O tradicionalismo, porém, não estava presente apenas no trabalho dos jesuitas, mas em outras correntes que fundamentavam sua instrução educativa, feita estritamente por um agente externo, na transmissão do conhecimento como verdades acabadas e em uma didática que primava pelo desenvolvimento de passos formais e por uma rígida estruturação desses conhecimentos. Conforme a classificação de Saviani (2009) e as reflexões de Libâneo (2002), tais tendências compõem o que se convencionou a chamar de pedagogia tradicional (tanto na vertente religiosa quanto na vertente leiga), de cunho liberal e não crítico, que prima pela manutenção da ordem vigente e pelo acúmulo enciclopédico de conhecimento. Nessa pedagogia tradicional, verifica-se o primado das verdades acumuladas pela humanidade, mesmo que, em muitos casos, desprovidas de significados sociais. É o caso da escola herbartiana, fruto do pensamento do alemão John Friedrich Herbart (1776-1841), o qual concebia a formação moral do caráter como fim supremo da educação, atingido por meio de uma instrução educativa que introduzisse ideias 
corretas na mente dos alunos. Por isso, afirma Libâneo (2002, p. 115) que "tanto para pedagogos católicos como para os herbartianos, somente uma pedagogia unitária pode formar um sistema orgânico de conceitos em torno dos fins e métodos da educação".

Entretanto, quando os portugueses chegaram para dominar as novas terras, as sociedades tribais já possuíam uma forma de transmitir seus conhecimentos aos mais novos. O pajé tinha certamente seu aprendiz para o qual repassava seus conhecimentos farmacológicos e ritualísticos, assim como os pais sabiam muito bem ensinar a seus filhos a arte da caça, da pesca e da fabricação do arco e da flecha, tal como a arte plumária, as peças de artesanato, as panelas e pinturas corporais que eram praticados por todos e todos ensinavam a todos. Eram, sem dúvida, processos informais e não formais de transferência do conhecimento comum. Mesmo o xamã, quando ensinava formalmente seu sucessor, não "dava aula" no sentido que compreendemos hoje, mas possibilitava situações de aprendizagem que podiam ocorrer a qualquer hora e em qualquer lugar. Igualmente, os povos africanos - dos quais foram retiradas milhares de pessoas para o trabalho escravo - também detinham uma forma própria de instruir seus filhos a fim de torná-los "pessoas" dentro de sua cultura, que não diferia muito das práticas de ensino e aprendizagem presentes nas tribos indígenas do Novo Mundo.

Lamentavelmente a leitura que os europeus fizeram das práticas autóctones foi etnocêntrica, desconsiderando tais ações como processos formativos. Em uma de suas cartas, Américo Vespúcio, por exemplo, escreve a um amigo dizendo que os índios "não tem lei nem fé alguma, vivem de acordo com a natureza e não conhecem a imortalidade da alma". E continua: "Não tem fronteiras entre províncias e reinos, não tem reis e não obedecem a ninguém" (citado por CALEFFI, 2005, p. 35). Não é que ignoravam leis, territórios e divindades, mas é que os tinham na memória porque não desenvolveram nenhuma forma de escrita e de institucionalização do ensino. Vespúcio traduzia, na verdade, o sentimento de superioridade que imperava no Velho Mundo em relação aos povos diferentes, principalmente os "selvagens", que, embasado pela Igreja, legitimou não apenas a invasão como a imposição cultural que se seguiu.

Mesmo que as circunstâncias da Europa fossem de renovação do conhecimento e reconstrução dos paradigmas intelectuais (GIDDENS, 1991), assim como de prosperidade de uma burguesia ativa e industriosa (CAMBI, 1999, p. 223), em sua tentativa de renovar as artes, as letras e as ciências, isto é, o conhecimento como um todo, em Portugal a Igreja e a Coroa mantinham ainda uma 
aliança estratégica contra a Reforma Protestante e, por extensão, contra toda essa sorte de reflexões que pudessem ser interpretadas como heresias. Ademais era conveniente a defesa de uma estrutura social hierarquizada "com o teológico primando sobre qualquer outra interpretação" (PAIVA, 2012, p. 27) para manter o poder. Com uma estrutura moralmente fechada e tripartite - o grupo dos que lutavam, outro dos que rezavam e o resto que trabalhava (HILSDORF, 2007) - o Reino mantinha a ordem das coisas e assegurava à nobreza os seus privilégios. A reação católica contra os movimentos reformistas, sobretudo no Concílio de Trento (1545-1563), teve amplo apoio em Portugal e Espanha, fazendo da Península Ibérica um reduto de resistência da velha ordem, o que gerou na sociedade portuguesa dos quinhentos um clima de desconfiança, policiamento e repressão às ideias destoantes dessa estrutura social e do conhecimento escolástico.

Nesse contexto, o ensino das primeiras letras, com mestres particulares nas casas, era algo que somente as famílias nobres ou abastadas poderiam propiciar a seus filhos. Não havia ainda a intenção de educar a "todos", como Comenius (2002) veio a defender depois, nem um plano educativo da Coroa para os habitantes das terras brasileiras, até porque, aos olhos daquela, estes não passavam de "criminosos e malfeitores" (PIERONI; VIANNA, 1999) e degredados à própria sorte. Mesmo assim, a aprendizagem da leitura, da escrita e dos cálculos só acontecia sob a autorização e a vigilância das autoridades eclesiásticas, de forma que o interesse pela criação das congregações de ensino, como a Companhia de Jesus, tinha como foco a manutenção da primazia eclesiástica, a reconquista da fé, da autoridade papal e do poder espiritual da Igreja, que havia sofrido os golpes do Renascimento e da Reforma. Em Portugal o lento processo da secularização não se fez em oposição à religião, mas pelo contrário, em favor da ampliação da autoridade sagrada, estendendo-a à pessoa do Rei - e por extensão, aos súditos - de tal forma que a colonização do Brasil passa a vislumbrar seu maior objetivo: a conversão do gentio à fé católica (PAIVA, 2012).

Portanto, é no espírito da evangelização que se desenvolve em Portugal o sentido de educação formal, queinfluencia substancialmente a formação da sociedade brasileira e o desenvolvimento dos processos educativos. Ora, diante de um continente a ser explorado, de uma nova realidade a ser conhecida e de povos diferentes a serem conquistados e evangelizados, a Coroa se viu na tarefa de "salvá-los", transmitindolhes seus fundamentos e visão de mundo. Em sua famosa carta, Pero Vaz de Caminha (1963, s/p) dizia ao Rei, sobre os índios: "Pareceme gente de tal inocência que, se homem os entendesse e eles a nós, 
seriam logo cristãos, porque eles, segundo parece, não têm, nem entendem em nenhuma crença". E admoestava: "Portanto Vossa Alteza, que tanto deseja acrescentar a santa fé católica, deve cuidar da sua salvação. E prazerá a Deus que com pouco trabalho seja assim". E encerrando a missiva diz: "Porém o melhor fruto, que nela se pode fazer, me parece que será salvar esta gente. E esta deve ser a principal semente que Vossa Alteza em ela deve lançar’. E foi nesse mesmo espírito de conversão do gentio que o projeto mercantilista da colonização se combinou com o projeto missionário da Igreja, pois o domínio espiritual auxiliou, ora em sintonia ora em distonia, nos propósitos de domínio material por parte da Coroa.

E nesse contexto que um grupo de estudantes da Universidade de Paris, sob a liderança de Iñigo López de Loyola (1491-1556), mais conhecido como Ignácio de Loyola, criou em 1534 a Companhia de Jesus, uma congregação religiosa - reconhecida pelo Papa em 1540 -, que viria logo a dominar a missão catequética e as principais instituições educativas, embora a educação não tenha feito parte das primeiras intenções de Loyola. Tendo este sido militar antes do sacerdócio, concebia uma guerra santa e, dessa forma, procurou estruturar seu grupo numa lógica de milícia e numa disciplina rigorosa de exercícios espirituais, regras, obediência e devoção: nada melhor para lutar contra a alteridade dos "hereges" reformistas, dos mouros maometanos e dos silvícolas "desalmados" no Novo Mundo. E isso não ia contra os interesses dos reis católicos, mas, pelo contrário, fortalecia seu poder e unia os povos sob uma só ideologia. Como diz Ferreira (2005, p. 62):

Os poderes estavam interessados nessa interpretação autoritária do saber e a escola jesuítica não tinha pátria porque o latim era sua língua, o catolicismo a sua ideologia e a escolástica a sua compreensão do mundo. Controlando o ensino, possuindo fortes convicções, munidos dum sólido saber instrumental, os inacianos conseguiram impor a sua visão da ciência e retardar a sua introdução do novo pensamento fundado na análise sistemática e, sobretudo, impedir a todo custo a difusão da filosofia cartesiana.

Embora os primeiros missionários que aportaram na terra brasilis em missão também evangelizadora tenham sido franciscanos ${ }^{2}$, desde 1549, quando aqui chegaram, os jesuítas souberam aproximarse dos índios, conviver com eles, aprendendo a cultura, a língua e descobriram logo como convertê-los. As aproximações incluíam mímicas, discursos emotivos, uso de instrumentos musicais e presentes. Diferente da "aculturação inversa" (BURKE, 2003, p. 66) que aconteceu com os jesuítas na $\mathrm{China}^{3}$, nas terras americanas, sobretudo no Brasil, os padres "puderam usar a força para impor o 
cristianismo aos índios", mas não sem aprender sobre sua cultura. Aprendendo a língua, tornaram-se intérpretes e, mais do que isso, ignoraram as diferentes culturas indígenas e empreenderam o recolhimento de crianças $^{4}$, o aldeamento de adultos e a utilização de uma língua geral com vistas a suprimir a visão de mundo dos selvagens e, assim, poder ensinar a nova cultura. Nesse sentido, as "casas de meninos" antecipavam os colégios que a Instituição estabeleceria depois para os filhos dos colonos até desenvolver um sistema nacional que atingiu quase a totalidade do território brasileiro e sobreviveu após sua expulsão, em 1759. No mundo todo a Companhia contava, logo antes de sua supressão, feita pelo Papa Clemente XIV em 1773, com 728 casas de ensino, entre colégios e seminários (FRANCA, 1952).

Sem diminuir a importância de franciscanos, dominicanos, agostinianos, mercedários, entre outros religiosos, os jesuítas superaram as demais ordens, tanto em número, quanto financeiramente, ou ainda nos objetivos de atingir todo o território brasileiro. Em sua tese, Origens da educação estatal na América Portuguesa, Damasceno (1998) afirma que a atuação dos religiosos na Amazônia substituiu por completo o poder civil no que diz respeito à educação de um povo, atingindo o mais longínquo rincão da Bacia Amazônica. $\mathrm{Na}$ História da instrução pública em Goiás, Bretas (1991) informa que, até o ano de sua supressão, 1759, foram registradas visitas dos religiosos jesuítas ao norte da Capitania em missões de catequese ${ }^{5}$ e incontáveis incursões pelos rios Tocantins e Araguaia. Descendo ou subindo os rios, ou seja, partindo do Planalto Central ou adentrando as matas a partir de Belém, tal como ocorreu em toda a Amazônia, a presença dos inacianos foi tão significativa e seu domínio tão vasto que nenhuma outra ordem se lançou à mesma tarefa, e a Coroa não conseguiu preencher a lacuna deixada por eles, embora seu inimigo declarado, o Marquês de Pombal (1699-1782), tenha intentado fazê-lo.

Diversas foram as razões pelas quais a Companhia ganhou inimigos e foi expulsa do Brasil e de Portugal, mas é importante salientar que uma delas inaugura a discussão do público e do privado na educação brasileira. A chamada "querela dos moços pardos", no início do século XVII, acirrou a disputa entre a Companhia e a Coroa acerca do caráter dos colégios. Por sua vez, os governantes reais afirmavam que a escola era pública, uma vez que os religiosos contavam com uma subvenção e, portanto, não poderiam negar a entrada de qualquer pessoa. Já os jesuítas afirmavam o seu caráter particular, pois a ajuda da Coroa se destinava à conversão dos índios e nada a tinha a ver com os cursos de humanidades, assim como 
os cursos superiores oferecidos pela organização. Sendo, de certa forma, "particular", poderiam recusar a presença de "pardos" e podiam escolher os alunos como lhes aprouvesse (CUNHA, 1986). Porém não é a intenção deste trabalho discutir a complicada temática em torno de público e privado nesse contexto, até porque, como afirma Paiva (2012), numa época em que Igreja e Coroa conviviam de forma complementar na tarefa de manutenção da sociedade, a ordem era sustentada e provida por ambas as partes, sem a distinção que hoje caracteriza tais espaços. Mesmo que em 1689 os colégios tenham se tornado "públicos" por uma carta régia, o esforço parece ter sido mais no sentido de desobrigação do Poder Real do que de promoção do livre acesso ao ensino - o qual prosseguiu nos mesmos moldes, sob o comando da Companhia.

\section{SOBRE O ENSINO JESUITTA: PRÓS E CONTRAS}

Vigorou por muito tempo entre os estudiosos a interpretação de que os jesuítas resistiram aos ventos da modernidade, reiterando as ideias próprias da Idade Média e posicionando-se à frente da Contrarreforma. Embora parte disso seja verdade, levavam-se mais em conta os aspectos negativos do trabalho educativo, como Gilberto Freyre em seu erudito estudo Casa-grande \& senzala (1943) e, mais recentemente, Gadotti (2002, p. 231) salientaram. Gadotti, por exemplo, que diz o seguinte:

\footnotetext{
Os jesuítas nos legaram um ensino de caráter verbalista, retórico, livresco, memorístico e repetitivo, que estimulava a competição através de prêmios e castigos. Discriminatórios e preconceituosos, os jesuítas dedicaram-se à formação das elites coloniais e difundiram nas classes populares a religião da subserviência, da dependência e do paternalismo, características marcantes de nossa cultura ainda hoje. Era uma educação que reproduzia uma sociedade perversa, dividida entre analfabetos e sabichões, os "doutores".
}

Atualmente as análises historiográficas buscam uma posição mediana entre uma tendência negativa e outra elogiosa em torno do tema da educação jesuíta. Muitos, como José Ricardo Pires de Almeida (1989), autor do livro História da Instrução Pública no Brasil (1500-1889), enaltecem o trabalho evangelizador da Ordem, sua organização e seu desenvolvimento, sem fazer nenhuma crítica. Diz ele na abertura de sua obra (1889, p. 25):

É incontestável que os jesuítas foram os primeiros educadores da juventude brasileira e foram também os pioneiros da civilização do país, onde lançaram os fundamentos de nossos edifício social, as bases segundo as quais formou-se nosso espírito público. 
Como afirmou Durkheim (1952), a arte e a originalidade da pedagogia dos jesuítas constituíram uma verdadeira revolução, que os colocou na perspectiva de superação das práticas educativas medievais em direção à pedagogia moderna. Indo além do que preconizava o método escolástico, era comum o uso da música e do teatro para o ensino das letras e das artes, assim como o desenvolvimento das manufaturas para despertar o gosto geral pelos estudos. Afinal, como diz Saviani (2011, p. 7), "os jesuítas tiveram que ajustar suas ideias educacionais, modificando-as segundo as exigências dessas condições", isto é, das imprevisíveis condições que enfrentaram, sobretudo no que o autor chama de período heroico (1549-1599) - que antecede a sistematização pedagógica, realizada pelo Ratio Studiorum. Em uma de suas cartas, O Padre Manuel da Nóbrega afirma que muitos meninos "aprendem a ler e escrever e vão muito avante; a cantar e tocar flauta; e outros, mamelucos mais destros, aprendem gramática" (citado por LEITE, 1938, p. 253). O próprio Nobrega intentou a implantação de um plano de estudos, antes do Ratio, ${ }^{6}$ que incluía, inclusive, a educação para o sexo feminino (SAVIANI, 2011).

Além do mais, destaca-se uma vasta historiografia mais recente, como os estudos de João Adolfo Hansen, principalmente em A civilização pela palavra (2011), e de José Maria de Paiva (1982), na obra Colonização e catequese e em seu artigo "Educação jesuítica no Brasil Colonial" (In: LOPES, FARIA FILHO \& VEIGA, 2011); de Gilberto Luiz Alves (2005) no livro O trabalho didático na escola moderna: formas históricas; de Amarildo Ferreira Júnior e Marisa Bittar (2004) no artigo "Pluralidade linguística, escola de bê-á-bá e teatro jesuítico no Brasil do século XVI", além de outros trabalhos. A partir dessa produção acadêmica, fica mais evidente a ideia de que, apesar do rigor metodológico, das práticas autoritárias e do diretivismo que caracterizam a pedagogia jesuítica, seu modus operandi pode ser considerado como "um germe importante da escola moderna" (ALVES, 2005, p. 58), principalmente pelo fato de que, diferentemente dos medievais, os jesuítas inovaram o trabalho didático com atividades de competição e debate; além, é claro, da composição na qual o aluno tinha liberdade para analisar um texto clássico - o que, na opinião de Demoustier (1997), possibilitava certa autonomia do estudante em relação ao professor.

Diferente da escolástica medieval, pautada pelo modus italicus de ensino - de caráter individual e equiparado ao trabalho artesanal -, os jesuítas estavam mais propensos ao modus parisiensis, isto é, a uma didática fundamentada nas relações coletivas, equiparadas ao trabalho manufatureiro. $\mathrm{O}$ modus parisiensis previa a organização dos alunos por classe - separando os da mesma faixa etária e/ou nível 
de conhecimento; a prescrição de exercícios e recompensas pelos acertos; e a exposição didática na estrutura da apresentação (lectio), levantamento das dúvidas (quaestiones), e debate entre os alunos e o mestre (disputatio). Sobretudo após o Concílio de Trento (15451563), houve uma revalorização da Retórica como instrumento de formação, buscando na oratória ciceroniana seu modelo, além das obras de Quintiliano e outros nomes da filosofia greco-romana. Como afirma Hansen (2011), a Retórica nunca foi elidida da pedagogia escolástica, mas somente após as discussões tridentinas é que passou a ser uma das principais disciplinas do ensino jesuítico, até porque, sem o domínio da retórica, seria difícil ao padre o uso do púlpito ou exercício do magistério na formação de novos sacerdotes. Mesmo assim, o exercício de memorização dos textos para o discurso eloquente não se tratava de uma erudição passiva, mecânica, mas de uma ação de análise, comparação e versatilidade, agregando as três faculdades: memória, vontade e inteligência. Dessa forma, é possível afirmarmos, apoiados em Franca (1952), que a educação brasileira teve em suas bases e em suas origens um currículo humanista (na vertente religiosa), o método parisiense de ensino e o espírito inaciano.

Quanto ao currículo, é preciso analisar o Ratio Studiorum. O Plano de Estudos da Companhia de Jesus, como um código de ensino elaborado para ser seguido em todo o mundo, resultou de sucessivas versões, culminando com a redação final de 1599, fruto da experiência pedagógica dos inacianos, das reflexões empreendidas em outros escritos, bem como do conteúdo que se ensinava na Universidade de Paris: Aristóteles, Quintiliano, Cícero, Erasmo, Tomás de Aquino e até dos tratados educacionais protestantes. Mas, como diz Franca (1952, p. 40), "foi com efeito na experiência palpitante dos colégios da Companhia que se foi estruturando seu plano definitivo de estudos". Talvez isso possa explicar seu caráter prático, pois não se trata de um tratado de pedagogia ou uma reflexão filosófica sobre o fenômeno educativo, mas de um conjunto de prescrições metodológicas, administrativas e curriculares, adotado, vale dizer, cinquenta anos após a chegada dos jesuítas ao Brasil.

Hábeis na gramática e na retórica, tanto em latim, quanto em grego ou nas línguas locais, seus professores buscavam desenvolver no aluno as chamadas humanidades (studia bumanitatis do humanismo renascentista), além dos conhecimentos teológicos. Nesse conjunto entravam os estudos de filosofia, de história, de geografia, de letras, música e artes, ou seja, mais ou menos o conteúdo das famosas Artes liberais, em contraposição às Artes mecânicas. De uma parte, o trivium (lógica, gramática e retórica) 
buscava a excelência do espírito pela linguagem, enquanto o quadrivium (aritmética, música, geometria e astronomia) contemplava os estudos da matéria, da compreensão do mundo físico. Mas não se pode negar que todo esse conhecimento estava sujeito de alguma forma à concepção teológica que permeava todo o processo, fazendo com que os alunos "respirassem" uma atmosfera de devoção a Deus: "A alma, porém, de toda a educação nos colégios da Companhia era a formação religiosa" (FRANCA, 1952, p. 74). É o que difere basicamente a eloquência jesuítica da eloquência latina, assim como da eloquência dos antigos sofistas.

Por outro lado, para quem possuía uma visão providencialista da história, educar significava converter, "desbarbarizar" o nativo e desenvolver os "bons costumes", difundir a fé e todas as virtudes cristãs, conforme os princípios da Igreja. É preciso considerar que a dimensão religiosa estava presente não apenas na formação dos clérigos, nos estudos superiores, mas na formação geral. Toda aula começava com uma oração e nas aulas de gramática a recitação privilegiava o catecismo:

Haja também às sexta-feiras ou aos sábados, por meia hora, uma exortação espiritual ou explicação da doutrina. Exortem-se principalmente os alunos à oração quotidiana a Deus, de modo particular à recitação diária do terço ou do ofício de Nossa Senhora; ao exame vespertino da consciência, à recepção freqüente e digna dos sacramentos da Penitência e da Eucaristia, à fuga dos maus hábitos, ao horror ao vício e finalmente à prática das virtudes dignas do cristão. (FRANCA, 1952, p. 181.5).

Daí o caráter disciplinador que encontrava eco também nas demais tendências tradicionais do ensino, cuja perspectiva era a formação do homem universal, imutável e objeto de uma essência pré-determinada. A sequência formal dos cinco passos - a preleção, a contenda, a memorização, a expressão e a imitação - reforçava o espírito um tanto quanto militar que tinha fundado a Companhia. Os melhores se tornavam oficiais, galgando as melhores patentes e gozando o prestígio e a posição hierárquica que sua vitória lhe proporcionava. Pelo que dispõe o Ratio, o ritual da memorização era uma constante, inclusive aos sábados, dia da sabatina do conteúdo estudado durante a semana. Não atendendo às expectativas, dentro ou fora da aula, cabia ao prefeito, (FRANCA, 1952, p. 190): "os castigos mais severos ou menos costumados, sobretudo por faltas cometidas fora da aula, como a ela remeta os que se recusam aceitar os castigos físicos, principalmente forem mais crescidos".

Da mesma forma, o estabelecimento dos feriados, os dias santos, a divisão da aula e demais procedimentos dos alunos e 
professores apresentados em todas as regras do Ratio serviram de modelo para a estrutura do ensino e da organização do ambiente escolar que se desenvolveu a longo dos séculos. Vejamos a atualidade do Método de corrigir os trabalhos escritos (FRANCA, 1952, p. 212-213): "Na correção dos trabalhos escritos, aponte as faltas cometidas contra as regras de gramática, de ortografia e de pontuação; observe se foram evitadas as dificuldades; explique tudo de acordo com as normas das regras da gramática" - o que não se diferencia muito do trabalho didático dos professores em geral, nos dias de hoje.

Entretanto, como argumentado antes, numa tensão entre o ranço escolástico na pedagogia do Ratio e as tendências modernas, os inacianos inovaram suas aulas (lectio) com um pouco de retórica, explorando os conhecimentos auxiliares advindos da produção clássica. Além do mais, os estudantes tinham certa liberdade para produzir textos argumentativos e apresentá-los. Mesmo os castigos, bastante utilizados no período medieval, e bem acentuados no Ratio, passaram a ter um sentido mais moral, deixando o castigo físico somente como último recurso (ALVES, 2005). Da mesma forma, essa inovação contemplou os trabalhos manuais, com a produção de manufaturas, contrastando um pouco com o caráter verbalista de sua educação, pelo qual Gadotti (2002) apresenta os jesuítas.

Nada disso, porém, negava o fim último e os objetivos gerais da Companhia, que visavam à educação integral do aluno e à preparação do bom cristão, bem na ideia de defesa do orbis christianus. Como diz Moraes, (1979, p. 28): "É o verbo, o Ratio Studiorum, é Santo Inácio, S. Francisco Xavier, Anchieta e a Companhia de Jesus que vão dizer ao mundo a palavra reveladora, que se consubstancia em catequese, apostolado, cultura e espírito".

Por outrolado, os jesuítas tinham em mente "prepararo homem concreto para viver no cenário deste mundo", conforme declara o Ratio (FRANCA, 1952, p. 75). Na última regra do documento, fica bem clara essa ideia: "Em conclusão proponham-se e variem-se os exercícios de modo que não só sejam úteis, senão também agradáveis e dignos, a fim de que os acadêmicos, com estas horas aprazíveis, sejam mais atraídos ao estudo" (FRANCA, 1952, p. 230, grifo meu). O que mais se aproximava da prática eram os "estudos de casos", nos quais se expunham exemplos de questões morais, como se era lícito cobrar juros, na perspectiva da lição pública emanada dos ensinamentos de sua teologia moral. Mesmo considerada importante, a condução das lições de casos era relegada aos "medianos", ou seja, aos incapazes de seguir os estudos de filosofia ou de teologia. O magistério da formação geral (Studia inferiora) era exercido pelos de talento mediano, 
tal como aponta o Ratio: "a saber, quando percebe e compreende o que ouve e estuda e é capaz de dar razão suficiente a quem lha pede" (FRANCA, 1952, p. 125). Em uma carta do Padre Hoffaeus, provincial da Germânia, ao provincial Borgia, geral da Companhia em Innsbruck, escrita em 18 de outubro de 1568, (citado por JULIA, 1997, p. 50, tradução livre) encontra-se a seguinte afirmação: 'Nossos professores das classes mais baixas são quase crianças, na maioria das vezes, são as mentes fracas e vacilantes na sua vocação".

Ou seja, o ofício de professor era um exercício constante das letras, da memorização e da arguição retórica, no nível da mediania, no qual não havia muito espaço para o livre pensamento e a exploração das ideias divergentes. A regra era clara: professores "que forem inclinados a novidades ou demasiado livres nas suas opiniões deverão, sem hesitações, ser afastados do magistério" (FRANCA, 1952, p. 123). A luta do padre Antônio Vieira (1608-1697) em defesa da liberdade dos índios é uma das notórias "opiniões livres", mas que não contradizia as concepções filosóficas da Companhia e sim a prática escravista dos colonizadores. Nisso, o padre agia conforme suas convicções e não foi omisso, tal como afirmou em um dos seus sermões: "A omissão é o pecado que com mais facilidade se comete, e com mais dificuldade se conhece, raramente se emenda" (VIEIRA, 1974, p. 68). Porém, foi omisso quanto à escravidão dos negros, sugerindo ao Rei que patrocinasse o fornecimento de escravos africanos aos colonos, até porque, como afirma Paiva (1982, p. 32), "os mais abalizados doutores da Igreja julgavam-na natural".

A perspectiva filosófica que embasava o trabalho dos Jesuítas era, na verdade, uma adequação do humanismo com a escolástica aristotélico-tomista. Mesmo assim, já havia uma distância considerável entre o ambiente dos colégios jesuíticos, substancialmente marcado pela competição e pelo mérito individual, e as aulas individuais dos mestres medievais (ALVES, 2005). Em termos gerais, entendese por escolástica a filosofia cristã da Idade Média, produzida por comentários e coletânea de questões sobre temas que auxiliassem a entender a verdade revelada. Método de pensamento dominante no ensino nas universidades, a escolástica nasceu nas escolas monásticas como tentativa de conciliar a fé com a razão, tendo como fonte filosófica o pensamento grego. Com base no silogismo de Aristóteles (384-322 a.C.), seu método de ensino consistia na lectio e na disputatio, devidamente conduzido para que ao final a determinatio não pudesse fugir à autoridade das Escrituras. Desde Anselmo de Cantuária (10331109) a Tomás de Aquino (1224-1274), a expressão maior da reflexão e do ensino era a da fé em busca da excelência pelo intelecto. Daí o 
termo "segunda escolástica" dado ao estágio da filosofia portuguesa, que começou com Pedro da Fonseca (1528-1597) se estendeu até meados do século XVIII (PAIM, 1974) e que se caracterizava pela retomada dessa forma de conduzir o raciocínio, assim como pela revalorização do argumento de autoridade, enfraquecido pelos ventos da Renascença e do Humanismo; ou ainda pela retomada dos dogmas eclesiásticos como arma para combater a reforma protestante. Isto é, uma espécie de ultramontanismo ${ }^{7}$ velado ou simples casuísmo que respaldou a rigorosa vigilância dos princípios estabelecidos, a formação catequética e a organização do ambiente escolar numa estrutura militarizada, bem como numa dinâmica hierárquica, sem espaço para a dúvida ou o livre pensar - bem próprio da escolástica que buscava levar o homem a compreender a verdade revelada. Podese dizer um obscurantismo de índole medieval, privado das reflexões que os tempos modernos propiciavam. Segundo Reale (1959, p. 17):

\begin{abstract}
É possível encontrar sobretudo entre os moralistas do período colonial, ou em escritos de natureza política, alguns traços de empirismo ou de "pragmatismo", mas é, sem dúvida, a orientação escolástica que prevalece, sem se esquecer que já no século XVII o escolasticismo português descambava para mero verbalismo vazio, destituído de interêsse especulativo.
\end{abstract}

Sem dúvida que esse tipo de educação foi um tanto quanto pernicioso. Em seu erudito estudo sobre o Brasil e a constituição de nossa sociedade, Gilberto Freyre (1943, p. 214) afirma:

\footnotetext{
Ainda mais: procuraram destruir, ou pelo menos castrar, tudo que fosse expressão viril de cultura artística ou religiosa em desacordo com a moral católica e com as convenções européias. Separam a arte da vida. Lançaram os fundamentos no Brasil para uma arte, não de expressão, de alongamento da vida e da experiência física e psíquica do indivíduo e do grupo social; mas de composição, de exercício, de caligrafia.
}

Porém, seria anacronismo culpar de um modo geral os jesuítas por esse obscurantismo. De certa forma os objetivos de sua Ordem sempre foram claros e a atuação educacional que se seguiu não fugia à lógica escolástica nem, tampouco, ao "espírito" das Constituições. Além do mais, as ações mais obscuras foram de iniciativa da Coroa, como exemplo, a proibição da imprensa nas terras brasileiras, em 1720, feita pela metrópole. Enquanto os aldeamentos eram produtivos, os nobres pertencentes à sociedade colonial não desatrelavam do ideal de "homem honrado" o desprezo pelo trabalho, de tal forma que "em pleno século XIX poderia escrever Pizarro serem os escravos os únicos que trabalhavam no Brasil" (PALACÍN, 1981, p. 185), sem deixar de esquecer que grande parte dos primeiros colonos era constituía por degredados e 
aventureiros sem muito interesse pelas ciências e artes. Em diversas ocasiões, os jesuítas defendiam os degredados, interessados em sua mão-de-obra, mas em carta ao Padre Geral, um religioso comentava: "Numa terra em que nascem uns bichos chamados preguiças, isto parece que se contagia à gente, e são muitos os que não querem darse ao trabalho do estudo, contentando-se com pouco, e caindo na ociosidade e suas faltas" (PALACÍN, 1981, p. 213).

Embora os jesuítas tenham aberto "escolas de ler e escrever" em quase todas as povoações e aldeias onde residiram, no princípio o progresso da educação foi um tanto quanto lento, mormente entre os filhos dos colonos que não viam muita vantagem na aprendizagem das primeiras letras e, conforme Cardim (citado por PALACÍN, 1981, p. 288), "tudo se leva em festas cantar e folgar". Afinal, o português buscava uma vida fácil nas terras descobertas, onde pudesse se estabelecer sem muito esforço ou conhecimento letrado, como aos poucos se exigia na metrópole. Assim, "atraídos pelas possibilidades de uma vida livre, inteiramente solta, no meio de muita mulher nua" (FREYRE, 1943, p. 112), poucos se davam ao trabalho da cultura letrada.

Como dito anteriormente, a nobreza e o clero do Reino português foram resistentes às "heresias" do cartesianismo, do empirismo e de outras correntes teóricas divergentes. Mesmo que a leitura fosse um privilégio de poucos, talvez de uns dez por cento da população, evitavam-se os escritos dos que se ocuparam com os problemas da educação, tanto protestantes como humanistas católicos contrários à escolástica, como o padre Rabelais. Contra uma educação formalista e livresca, o autor de Gargântua (RABELAIS, 1946) e Pantagruel (RABELAIS, 1952) antecipou a magistral reflexão educacional de Jean-Jacques Rousseau (1712-1778) no Emílio on da educação (ROUSSEAU, 1973) e escreveu igualmente uma novela pedagógica na qual relatava o esforço de vinte anos de educação do gigante Gargântua o qual, à medida que decorava diversos livros, como notara seu pai, ficava mais tolo e idiota. Mudando o preceptor, a educação passou a ser trabalhada por meio de viagens, através de jogos, ginástica e passeios pelo campo, de forma intuitiva. ${ }^{8}$ Rousseau bem conhecia o dogmatismo da pedagogia jesuítica e também os vários tratados de educação que não deixavam de todo a velha retórica: "Nunca repetirei bastante que damos demasiada importância às palavras; com nossa educação tagarela, não fazemos senão tagarelas." (ROUSSEAU, 1973, p. 191). Os Ensaios, de Montaigne, são outro exemplo de crítica à educação pedante e livresca dos jesuítas, a qual também dominava os colégios em Portugal. Da mesma forma, o discurso cartesiano sobre o método alçava a dúvida como a posição primordial e inicial do 
pensamento. Tendo sido aluno dos jesuítas no Colégio de La Flèche, Descartes era consciente da necessidade de buscar novas bases para o conhecimento, assim como para a forma de ensiná-lo.

Outrossim, com avanço do Iluminismo, o debate se fortaleceu e a reação antiescolástica tomou corpo nas reflexões de pedagogos e filósofos. Destaca-se, nesse contexto, o religioso Luís António Verney (1713-1792) que escreveu uma série de cartas cujo conjunto foi compilado com o título de O verdadeiro método de estudar (VERNEY, 1965). Logo na primeira carta o autor defende que "não se devem intimidar os rapazes com mau modo ou pancadas, como todos os dias sucede; mas com grande paciência (...) e quando os rapazes estivessem mais adiantados, obrigá-los-ia a escrever algumas cartas a diversos assuntos". Na segunda carta diz: "Quem obriga os rapazes a aprender muito verso e muita arenga, faz-lhes mal, cuidando fazerlhes bem”. E sobre a lógica aristotélica, Verney (1965, p. 55) dizia:

\footnotetext{
Este é o grande defeito que eu acho nestas Lógicas: não buscarem aquelas coisas em que todos convêm, para as explicar aos estudantes; não acharem um método de ensinar Lógica, começando por documentos claros, que todos entendam, fugindo todo o género de disputas, que não servem para principiantes.
}

Por estas e outras observações feitas ao longo de suas dezesseis cartas, podemos dizer que Verney defendia um ensino prático e baseado na realidade concreta, e ainda custeado pelo Estado. Outros olhares críticos sobre a arcaica organização da sociedade portuguesa buscaram refletir sobre a possibilidade e os meios de formar os moços para a vida civil, valorizando a ideia de Estado, os princípios da liberdade e da ordem mercantil que se desenvolviam. Em suas Cartas sobre a educaşão da mocidade (SANCHES, 2003), Ribeiro Sanches (1699-1783) afirmou que já era necessária outra educação, diferente do catecismo religioso ou do ócio da nobreza. Afinal, o Estado tinha necessidade de súditos instruídos em outros conhecimentos: já não necessitavam, segundo ele, do ânimo altivo, guerreiro e da fé que os levavam a ser cavaleiros ou eclesiásticos (SANCHES, 2003).

Tais reflexões influenciaram diretamente o Marquês de Pombal, ministro de D. José I (1714-1777), que, como uma espécie de déspota esclarecido, intentou a modernização das instituições portuguesas, entre elas o ensino e a instrução pública. Contrário à atuação dos jesuítas, o marquês os expulsou em 1759, confiscandolhes os bens. E foi nesse ímpeto que esse ilustrado lusitano, como expressão de um grupo contrário ao pensamento escolástico, intentou modernizar o Reino, principalmente no que dizia respeito ao comércio, à jurisprudência e à instrução pública, na perspectiva de 
um Estado secular. Tal como Damasceno (1998) busca discutir em sua tese, se em toda a América Portuguesa o ensino sempre foi de iniciativa religiosa, a política pombalina pode ser caracterizada como secular e estatal, malgrado a presença de outras Ordens e da religião católica como "oficial" das terras lusitanas.

No Brasil foram implantadas as chamadas aulas régias de conteúdo humanista, ilustrado e com foco nas ciências. Mas, talvez por influência do pensamento de Sanches - o qual não aprovava uma massiva e imediata educação do povo -, ou simplesmente for falta de fundos, a iniciativa foi mais significativa nas capitais das províncias ${ }^{9} \mathrm{e}$ a instrução primária continuava uma oportunidade acessível a poucos. Fora os parcos liceus, o ensino secundário era oferecido por aulas avulsas, oferecidas na própria casa do professor ou em pequenas salas alugadas, sem deixar de comentar que não se exigia dos professores nenhum diploma, mas somente uma prova que, muitas vezes era burlada pela influência do candidato sobre a câmara de vereadores ou ao comissário de estudos, nomeado pelo Diretor Geral dos Estudos.

Mesmo tendo sido uma novidade e uma iniciativa assaz bem intencionada, as aulas régias não funcionaram no sentido de educação pública e com vistas a atender todo o território. Nem com o subsídio literário, de 1772, foi possível ampliar o atendimento. Para ilustrar, um alvará de 1773 aumentava de 17 para 19 o número de Escolas Menores. Número insignificante que atendia, evidentemente, apenas aos filhos de uns poucos "homens bons", como eram chamados os nobres e senhores de recursos. E somente em 1827 a lei de 15 de outubro tornou obrigatória a instalação de escolas em todas as vilas e povoações do país. O que era obrigatório ao governo - embora não tenha cumprido -, não o era para o povo. A população continuou iletrada tal como antes. Ademais, o termo "escola" era aplicado à cadeira disciplinar: Primeiras letras, latim, filosofia, etc., e não precisamente a uma sala de aula ou a um prédio escolar, como se configurou com o Colégio D. Pedro II, no Rio de Janeiro, e os "templos do ensino" edificados pelo ideário positivista que influenciou a Primeira República.

Da mesma forma, é bom lembrar que a colônia era distante da metrópole e, se os Directórios e Alvarás chegavam com certa rapidez, não encontravam a quantidade de professores suficiente e bem preparados. Dos que aqui se ofereceram ao ofício, a maioria fora educada pelos jesuítas e seu conhecimento, assim como o método pedagógico, não sofrera a desejada reforma ilustrada, após a expulsão dos padres. Nesse sentido, é preciso concordar com Cartolano (1985, p. 25), que diz:

O ensino orientou-se ainda para os mesmos objetivos religiosos e livrescos dos jesuítas; realizou-se através dos mesmos métodos pedagógicos, com 
apelo à autoridade e à disciplina estreitas, tendendo a impedir a criação individual, a originalidade. Quanto ao ensino de filosofia, continuou também no mesmo estilo livresco e escolástico.

\section{À GUISA DE CONCLUSÃO: 0 LEGADO PÓS-JESUÍTA}

Por mais de dois séculos o ensino jesuíta foi o mesmo, quase sempre baseado nos princípios clássicos de transmissão de conteúdo acadêmico e de estudos religiosos. Embora a prática pedagógica tenha sido um pouco afastada do rigor medieval, e suas aulas tenham avançado nos conhecimentos humanistas, permanecia a ideia da ordem como virtude, bem como o objetivo da salvação. Porém, também amparado na perspectiva tomista, o ensino da Ordem defendia que, tendo os homens uma tendência natural para o intelecto - como defendia o pensamento escolástico, fortemente amparado na filosofia aristotélica -, o esforço da filosofia deveria, apontar para a promoção das relações entre as virtudes morais, as estéticas e as intelectuais, a fim de conduzir a natureza humana ao desenvolvimento conjunto do corpo e da alma, como melhor forma de se chegar a Deus (AQUINO, 2004). Se Deus é puro intelecto, como afirmou em sua Súmula teológica (AQUINO, 2004), a verdade em nosso intelecto deve conformar-se ao intelecto divino. A partir dessa concepção é que se desenvolveu uma educação mais contemplativa, resultando em uma formação passiva e conformadora, a qual se realizava por meio de uma pedagogia da repetição, tanto do conteúdo como da didática, e não em uma formação para a reflexão e para o pensamento crítico.

Vale lembrar que no período jesuítico o religioso protestante Comenius (1592-1670) produziu uma reflexão um tanto quanto diferente da concepção jesuítica e ajudou a consolidar a Didática como um campo de conhecimento próprio. O pedagogo morávio defendia o ensino de tudo a todos, realizado de forma dinâmica, prazerosa, fácil, e a partir de experiências cotidianas. Seus escritos deram início a um repensar da infância, das metodologias de ensino, do espaço escolar e da organização do trabalho pedagógico. Abandonando uma perspectiva artesanal - que caracteriza o trabalho dos jesuítas -, a organização escolar e a didática pensadas por Comenius estavam mais dentro da perspectiva manufatureira do trabalho didático - mais próprio ao mundo moderno que se descortinava.

Todavia, é preciso elogiar, na pedagogia jesuítica, os momentos de exposição de poesias, que implicavam a produção literária dos alunos e os desafios, que consistiam em momentos de disputa de conhecimento. 
Mesmo que a meritocracia daí resultante possa ser classificada como seletiva, alguns poderiam sentir a necessidade de superar o colega e, ao mesmo, superar-se a si mesmo. O uso do teatro, malgrado a proibição de espetáculos públicos, pode ser considerado a prática mais dinâmica, uma vez que trabalhava com os conteúdos, com a memória, com a desinibição e com a apreciação estética ao mesmo tempo.

Seu legado compreende, portanto, uma visão de mundo, uma concepção de educação e uma prática pedagógica que ajudaram a edificar o que comumente se chama de escola ou pedagogia tradicional. Tanto na versão religiosa (desenvolvida pela Igreja em seus estabelecimentos de ensino), como na versão laica (desenvolvida pela iniciativa governamental) a pedagogia jesuítica está bem presente, embora acrescida de várias outras influências, como o pensamento positivista, as contribuições de Herbart e, em alguns aspectos, a pedagogia de Johann Hendrich Pestalozzi (1746-1827).

Bem parecidas na prática pedagógica, o que diferencia basicamente as duas versões é o deslocamento da compreensão da origem da essência humana em Deus para a ideia de natureza como lócus referencial do saber. Termo bastante utilizado no século XVIII, sobretudo pelos intelectuais iluministas e os chamados filósofos naturais, o sentido de natureza está presente desde o estoicismo antigo, passando pelo paganismo. Mas foi no contexto das discussões iluministas que ele ganhou um sentido ontológico, essencial e, portanto, próprio para substituir a ideia de Deus, por sua dimensão transcendental (EHRARD, 1994).

Entretanto, essa nova perspectiva ontológica, as reflexões de Comenius, as reflexões dos iluministas e as teorias que se desenvolveram ao longo dos séculos XVIII e XIX, por influência do pensamento de Rousseau, não foram suficientes para uma mudança imediata na educação como um todo e na escola brasileira. Por exemplo, mesmo que amparada no método intuitivo, fortemente influenciado por Rousseau, pela "lição das coisas" pestalozziana e sua defesa do ensino como uma atividade livre, a apreensão do conhecimento ainda tinha um caráter passivo por parte do aluno. O professor era ainda o centro do processo, demonstrando os objetos (as coisas), tal como explicando os conceitos, e possibilitando os modos mais práticos para facilitar a memorização. Nisso o autor se afastou de seu mestre, Rousseau, o qual foi contra a memorização e a centralidade do professor.

A organização pensada por Herbart, para dar outro exemplo, não se distanciava muito, em sua estrutura, da dos religiosos inacianos, a saber: governo, disciplina e instrução. Ou seja, tendo em vista a formação por via da instrução, o condutor do processo devia ter 
o controle para manter o interesse do aluno, dirigindo o conteúdo de tal forma que fosse bem absorvido pelos estudantes. Para tanto, precisava estipular regras, exercícios e até controle do tempo da aula a fim de auxiliar na disciplina, na ordem e no desenvolvimento geral dos estudos. O positivismo pedagógico herbartiano seguia muito bem a cartilha durkheimiana da transmissão do conhecimento e da preparação das novas gerações com de etapas rigidamente estruturadas do desenvolvimento. Ou seja, o professor deveria seguir quatro etapas (ou passos formais) bem específicas e ordenadas: demonstração, comparação, generalização e aplicaşão, para bem conduzir sua aula.

$\mathrm{O}$ formalismo racionalista que se seguiu acabou impedindo o desenvolvimento da perspectiva empirista e prática da produção do conhecimento, assim como dificultando, por um lado, o avanço dos diversos aspectos renovadores da pedagogia escolanovista. Por outro lado, o tradicionalismo reforçou a resistência contra a capacidade crítica e problematizadora da pedagogia progressista.

Analisando essas raízes, o que ficou substancialmente como herança para as práticas educacionais brasileiras não foi o currículo clássico, universalista, com conteúdos capazes de desenvolver os juízos críticos, por meio do Trivium, ou ainda da compreensão do espaço físico, por meio do Quadrivium, mas seu caráter hierárquico, elitista, formalista, meritocrático e dogmático. Herdamos tão somente um utilitarismo que empobreceu os currículos, tendo em vista que se passou a valorizar mais o processo que o conteúdo. Encampada pela própria UNESCO, essa perspectiva defende que as escolas devem dar resposta às novas necessidades, quais sejam a de formar profissionais estritamente necessários, cientistas e técnicos para o inovador mercado de trabalho que se apresenta na atualidade (DELORS, 2003). Valem o crescimento econômico, as habilidades técnicas e a formação da mão de obra e não mais o desenvolvimento humano, a formação da cultura geral, ou a formação dos talentos culturais - que, de alguma forma, estavam presente na educação dos "soldados" de Loyola.

\section{REFERÊNCIAS}

ALMEIDA, J. R. P. de. História da Instrução Pública no Brasil (1500-1889). Trad. Antonio Chizzotti. São Paulo: EDUC; Brasília, INEP/MEC, 1989.

ALVES, G. L. O trabalho didático na escola moderna: formas históricas. Campinas, SP: Autores Associados, 2005.

AQUINO, T. de. Textos selecionados. São Paulo: Nova Cultural, 2004. (Coleção Os Pensadores). BRETAS, G. F. História da instrução pública em Goiás. Goiânia: CEGRAF/UFG, 1991. (Col. Documentos Goianos, n. 21). 
BURKE, Peter. Hibridismo cultural. Trad. Leila Souza Mendes. São Leopoldo, RS: Editora UNISINOS, 2003. (Coleção Aldus, v. 18).

CALEFFI, P. Educação autóctone nos séculos XVI ao XVIII ou Américo Vespúcio tinha razão? In: STEPHANOU, M.; BASTOS, M. H. C. (Org.). Histórias e memórias da educação no Brasil. 2. Ed. Petrópolis, RJ: Vozes, 2005. v. 1 - séculos XVI-XVIII.

CAMBI, Franco. História da Pedagogia. São Paulo: UNESP, 1999.

CAMINHA, P. V. Carta a El Rei D. Manuel. São Paulo: Dominus, 1963. Disponível em: http:/ / www.dominiopublico.gov.br/pesquisa/PesquisaObraForm.do. Acesso em: 21 out. 2013.

CARTOLANO, M. Filosofia no ensino de $2^{\circ}$ grau. São Paulo: Cortez, 1985.

CHANEL, É. Grandes temas da pedagogia. Trad. Maria José Gonçalves Almeida. Rio de Janeiro: F. Alves, 1977.

COMENIUS. Didática Magna. Aparelho crítico: Marta Fattori; tradução Ivone Castilho Benedetti. 2. ed. São Paulo: Martins Fontes, 2002.

CUNHA, A. 1996. A universidade temporã. Rio de Janeiro: Francisco Alves, 1986.

DAMASCENO, A. Origens da educação estatal na América Portuguesa. 1998. 240 f. Tese (Doutorado em Educação) - Dpto. de Educação, Pontifícia Universidade Católica de São Paulo, São Paulo.1998.

DELORS, J. Educação: um tesouro a descobrir. Relatório para a UNESCO da Comissão Internacional sobre Educação para o século XXI. 8. ed. São Paulo: Cortez Editora; BrasíliaDF: MEC: UNESCO, 2003.

DEMOUSTIER, A. Les jésuites et l'enseignement à la fin du XVIe. siècle. In: RATIO STUDIORUM. Plain raisonné et institution des éstudes dans la Compangnie de Jésus. Édition bilingue Latin-français. Paris: Belin, 1997.

DURKHEIM. Émile. Educação e sociologia. Trad. Lourenço Filho. $3^{\text {a }}$. ed. São Paulo: Melhoramentos, 1952.

EHRARD, J. L'idée de nature en France dans La première moitié du XV III siècle. Paris: Albin Michel, 1994. FERREIRA, A. G. A educação no Portugal barroco: séculos XVI e XVIII. In: STEPHANOU, M.; BASTOS, M. H. C. (Org.). Histórias e memórias da educação no Brasil. 2. ed. Petrópolis, RJ: Vozes, 2005. v. 1 - séculos XVI-XVIII.

FERREIRA JÚNIOR, A.; BITTAR, M. Pluralidade linguística, escola de bê-a-bá e teatro jesuítico no Brasil do século XVI. Rev. Educação e Sociedade, Campinas, v. 25, n. 86, p. 171-195, abr. 2004. Disponível em: <http://www.cedes.unicamp.br>. Acesso e: 25 jul. 2013.

FRANCA, L. O método pedagógico dos jesuítas: O Ratio Studiorum. Rio de Janeiro: Agir, 1952.

FREYRE, G. Casa-grande \& senzala. 4. ed. Rio de Janeiro: José Olympio, 1943.

GADOTTI, M. História das Ideias Pedagógicas. 8. ed. São Paulo: Ática, 2002.

GIDDENS, A. As consequências da modernidade. Tradução de Raul Fiker. São Paulo: Editora UNESP, 1991.

HANSEN, J. A. A civilização pela palavra. In: LOPES, E. M. T.; FARIA FILHO, L. M. de; VEIGA, C. G. 500 anos de educação no Brasil. 5. ed. Belo Horizonte: Autêntica, 2011.

HILSDORF, M. L. S. História da Educação Brasileira: leituras. São Paulo: Thomson Learning, 2007. JULIA, D. L'élaboration de La Ratio Studiorum, 1548-1599. In: RATIO STUDIORUM. Plain raisonné et institution des éstudes dans la Compangnie de Jésus. Édition bilingue Latin-français. Présentée par Adrien Demoustier et Dominique Julia. Traduite par Léone Albrieux et Dolorès Pralon-Julia. Annotée et commentée par Marie-Madeleine Compère. Paris: Belin, 1997. 
LEITE, S. História da companbia de Jesus no Brasil. Lisboa, 1938.

LIBÂNEO, J. C. Pedagogia e pedagogos, para quê? 5. ed. São Paulo: Cortez, 2002.

LOPES, E. M. T.; FARIA FILHO, L. M. de; VEIGA, C. G. (Org.). 500 anos de educação no Brasil. 5. ed. Belo Horizonte: Autêntica, 2011.

MELLO, A. de O. As minas reveladas: Paracatu no tempo. Paracatu: Prefeitura Municipal, 1994.

MILLER, J. R. Shingwank's vision: A history of native residential schools. Toronto: Bufallo; London: University of Toronto Press, 1996.

MONTAIGNE, Michel de. Ensaios (Vol. 1). Trad. Sérgio Millet. São Paulo: Ed. Nova Cultural, 2004 (Coleção Os Pensadores).

MORAES, G. D. de. A Igreja e o Colégio dos Jesuitas de São Paulo. São Paulo: Prefeitura do Município, 1979.

PAIVA, J. M. de. Religiosidade e cultura brasileira: séculos XVI-XVII. Maringá: Eduem, 2012. Colonização e catequese (1549-1600). São Paulo: Autores Associados: Cortez, 1982.

PIERONI, G.; VIANNA, M. Os degredados na colonização do Brasil. Brasília: Thesaurus, 1999.

PALACÍN, L. Sociedade colonial (1549 a 1599). Goiânia: Ed. da Universidade Federal de Goiás, 1981.

PAIM, A. História das idéias filosóficas no Brasil. 2. ed. São Paulo: Grijaldo, 1974.

RABELAIS, François. Gargantua. Texte établi et presente par Jean Plattard. $3^{a}$. Ed. revue et corrigée. Paris: Société Les Belles Lettres, 1946.

Pantagruel. Introduction et notes de Louis Desgraves. Paris: Delmas, 1952.

RATIO STUDIORUM. Plain raisonné et institution des éstudes dans la Compangnie de Jésus. Édition bilingue Latin-français. Présentée par Adrien Demoustier et Dominique Julia. Traduite par Léone Albrieux et Dolorès Pralon-Julia. Annotée et commentée par Marie-Madeleine Compère. Paris: Belin, 1997.

REALE, M. Filosofia em São Paulo. São Paulo: Conselho Estadual de Cultura, 1959.

ROUSSEAU, J-J. Emílio ou da educação. 2. ed. São Paulo: DIFEL, 1973.

SANCHES, A. R. Cartas sobre a Educaşão da Mocidade. Covilhã, Portugal: Universidade da Beira Interior, 2003.

SANGENIS, L. F. C. Franciscanos na educação brasileira. In: STEPHANOU, M.; BASTOS, M. H. C. (Org.). Histórias e memórias da educaşão no Brasil 2. ed. Petrópolis, RJ: Vozes, 2005. v. 1 - séculos XVI-XVIII.

SAVIANI, D. História das ideias pedagógicas no Brasil. 3. ed. Campinas, SP: Autores Associados, 2011. Escola e democracia. Campinas, SP: Autores Associados, 2009.

VERNEY, L. A. Verdadeiro método de estudar. Lisboa: Verbo, 1965.

VIEIRA, Pe. A. Sermões. Texto integral. São Paulo: Editora Três, 1974.

\section{NOTAS}

${ }^{1}$ A intensa discussão se os povos diferentes eram "animais", portanto sem alma, ou "homens", foi resolvida pela bula Sublimis Deus, de 1537, assinada por Paulo III. Caso fossem "feras" ou "coisas", como eram considerados os negros, isso invalidaria o trabalhos dos jesuítas na tentativa de convertê-los à fé cristã. 
${ }^{2}$ Temos notícia de que a primeira escola do Brasil foi fundada por dois franciscanos, em Santa Catarina, no ano de 1538 (SANGENIS, 2004).

${ }^{3}$ Peter Burke (2003), no livro Hibridismo cultural, informa que os jesuítas se acomodaram tanto à cultura local que foram acusados por seus críticos de terem sido convertidos pelos chineses, uma vez que se vestiam como os chineses, não atacavam seus rituais e aceitavam seus mitos.

${ }^{4}$ Como fizeram em toda a América, inclusive no Canadá (Cf. MILLER, 1996).

${ }^{5}$ Tomando o conceito de Paiva (1982, p. 51): "Por catequese se entenderá toda a ação pastoral da Igreja: a doutrinação expressa, a prática devocional e o próprio comportamento dos cristãos”.

${ }^{6} \mathrm{O}$ termo ratio pode ser utilizado com o artigo definido no masculino ou no feminino. Em latim, a palavra é feminina, mas o aqui me refiro ao livro Ratio studiorum e opto pelo gênero masculino.

${ }^{7}$ Movimento de valorização extrema da pessoa do Papa, sua prerrogativa sobre os governantes terrenos e seu poder nas questões de fé.

8 "O conhecimento intuitivo, que é imediato, opõe-se ao conhecimento discursivo, que é mediato, que resulta de uma demonstração, de um raciocínio” (CHANEL, 1977, p. 179).

${ }^{9}$ É possível que algumas iniciativas nesse sentido tenham sido tomadas em algumas cidades do interior. Por exemplo, mesmo que não tenha encontrado registros que comprovem se foram realmente efetivadas, Mello (1994, p. 125) comenta sobre a criação de cadeiras de Retórica e Filosofia em Paracatu, em 1821.

Recebido: 26/06/2014

Aprovado: 15/04/2015

Contato:

Pontifícia Universidade Católica de Goiás Escola de Formação de Professores e Humanidades/PPGE Rua 227, Quadra 66, n. 3669

Setor Leste Universitário

Goiânia|UF|Brasil

CEP 75.380-000 